\section{Viral Subunits for Rabies Vaccination}

RECENT work with adenovirus ${ }^{1}$, Sindbis virus ${ }^{2}$ and the viruses causing influenza ${ }^{3}$, measles ${ }^{4}$, vesicular stomatitis ${ }^{5}$ and German measles ${ }^{6}$ has shown that subunits of the viruses can stimulate the production of neutralizing antibodies, and in some cases can be used as vaccines. Subunits are usually present in unfractionated virus preparations and in the case of the lipid-containing viruses can also be produced from complete virus particles by treating with 'Tween'-ether or a detergent, for example, sodium deoxycholate or sodium dodecyl sulphate. The use of subunits for immunization has the important advantage that it avoids the side effects from other components of the virus. We report here preliminary experiments with rabies virus in which subunits separated from virus suspensions were shown to be potentially useful for protection against the disease.

The Flury (LEP) strain of virus was used for all the experiments. Both the virus and the mice used in the tests were free from lymphocytic choriomeningitis virus. A suspension prepared from the brains of suckling mice infected with Flury virus was inactivated by incubating with 0.05 per cent acetylethyleneimine at $37^{\circ} \mathrm{C}$ for $7 \mathrm{~h}$. Virus inactivated by this method was innocuous for 7 days old mice when inoculated intracerebrally. Samples of $1 \mathrm{ml}$. of serial five-fold dilutions were then inoculated intraperitoneally into 8 weeks old mice. The level of neutralizing antibody in the sera at various intervals after a single inoculation was determined by measuring the reduction in titre in suckling mice produced by mixing serial ten-fold dilutions of rabies virus with an equal volume of inactivated $1 / 10$ serum. The neutralizing antibody titre reached a plateau 14 days after inoculation and was roughly proportional to the amount of antigen in the inoculum up to the dose containing the equivalent of $10^{6.3} \mathrm{ID}_{50}$. With larger doses the response did not increase (Table 1). By titrating the virus in groups of 8 weeks old mice which had received serial dilutions of inactivated virus we also found a correlation between the neutralizing antibody level of the serum and resistance to infection (Table 1). These results indicate that the neutralization test provides a sensitive and valid measure of immunogenicity. Consequently, we have used this test in preference to the Habel? test for measuring the potency of our preparations. Our method has the advantage that only a single inoculation is necessary to give a measurable response whereas in the Habel test multiple doses of the vaccines are inoculated before the animals are challenged with live virus.

Table 1. RELATION BETWEEN DOSE OF RABIES VACCINE, NEUTRALIZING AN'IBODY LEVEL AND RESISTANCE TO CHALlENGE IN ADULT MICE

\begin{tabular}{|c|c|c|c|c|c|c|}
\hline $\begin{array}{l}\text { Dilution } \\
\text { of } \\
\text { vaccine }\end{array}$ & $\begin{array}{c}\text { Titre of } \\
\text { inoculum before } \\
\text { inactivation } \\
\left(\log \mathrm{ID}_{50} / \mathrm{ml} .\right)\end{array}$ & $\begin{array}{r}\text { Antil } \\
\text { mice 2 } \\
\text { (log ID }\end{array}$ & $\begin{array}{l}\text { dy ti } \\
\text { days }\end{array}$ & $\begin{array}{l}\text { in in } \\
\text { ter in }\end{array}$ & $\begin{array}{l}\text { jidual } \\
\text { ulation } \\
\text { serum) }\end{array}$ & $\begin{array}{c}\text { Titre of } \\
\text { challenge } \\
\text { virus } \\
\left(\log 1 D_{50} / \mathrm{ml} \text {.) }\right.\end{array}$ \\
\hline $\begin{array}{l}1 / 1 \\
1 / 5 \\
1 / 25 \\
1 / 125 \\
1 / 625 \\
\text { Control }\end{array}$ & $\begin{array}{l}7 \cdot 0 \\
6 \cdot 3 \\
5 \cdot 6 \\
4 \cdot 9 \\
4 \cdot 2 \\
-\end{array}$ & $\begin{array}{l}3 \cdot 5 \\
3 \cdot 9 \\
1 \cdot 7 \\
0 \cdot 5 \\
0 \cdot 7 \\
0 \cdot 2\end{array}$ & $\begin{array}{l}3 \cdot 9 \\
3 \cdot 9 \\
2 \cdot 5 \\
0 \cdot 5 \\
0 \cdot 3 \\
0 \cdot 4\end{array}$ & $\begin{array}{l}3 \cdot 9 \\
3 \cdot 7 \\
2 \cdot 7 \\
1 \cdot 7 \\
0 \cdot 5 \\
0 \cdot 4\end{array}$ & $\begin{array}{l}3 \cdot 5 \\
4 \cdot 0 \\
3 \cdot 1 \\
2 \cdot 7 \\
1 \cdot 3 \\
\end{array}$ & $\begin{array}{l}2 \cdot 8 \\
2 \cdot 5 \\
3 \cdot 5 \\
3 \cdot 5 \\
4 \cdot 8 \\
4 \cdot 8\end{array}$ \\
\hline
\end{tabular}

To determine whether viral subunits would elicit an immune response, a virus suspension prepared from suckling mouse brains was centrifuged for $2 \mathrm{~h}$ at 15,000 r.p.m. in the 40 rotor of the Spinco model $L$ centrifuge. The top $9 \mathrm{ml}$. was first removed, then the bottom $2 \mathrm{ml}$, taking care not to disturb the pellet. The resuspended pellet and each fraction were diluted to the original volume of $11 \mathrm{ml}$. Aliquots of the unfractionated virus and of each fraction were inactivated with acetylethyleneimine and serial dilutions were inoculated intraperitoneally into 8 weeks old mice. The virus neutralizing activities of the sera of the mice after 21 days (Table 2 ) showed that the immunizing activity in the supernatant fractions of the virus was considerably greater than would be expected from the amount of virus they contained. Van den Ende, Polson and Turner ${ }^{8}$ also found that the 15,000 r.p.m. supernatant from mouse brain suspensions elicited the formation of neutralizing antibodies in mice, but they attributed this immunogenic activity to residual infective virus.

Table 2. PRODUCTION OF NEUTRALIZING ANTIBODY IN ADULT MICE BY INOCLLATIYG TRACTIONS OF INAGIVATED RABIES VIRTS

\begin{tabular}{|c|c|c|c|c|}
\hline $\begin{array}{l}\text { Dilution } \\
\text { of } \\
\text { inoculum }\end{array}$ & $\begin{array}{c}\text { Cnfractionated } \\
\text { virus } \\
\left(10^{8} \cdot 8\right. \\
\left.I D_{50} / \mathrm{ml} .\right)\end{array}$ & $\begin{array}{l}15,000 \mathrm{rev} / \\
\mathrm{min} \text {. deposit } \\
\left(10^{6 \cdot \mathrm{y}}\right. \\
\left.\mathrm{ID}_{50} / \mathrm{ml} .\right)\end{array}$ & $\begin{array}{c}\text { Top } 9 \mathrm{ml} \text {, of } \\
\text { supernatant } \\
\left(10^{3 \cdot 4}\right. \\
\left.\mathrm{ID}_{50} / \mathrm{ml} .\right)\end{array}$ & $\begin{array}{c}\text { Bottom } 2 \mathrm{ml} \text {. } \\
\text { of supernatant } \\
\left(10^{3 \cdot 2}\right. \\
\left.\mathrm{ID}_{5} / \mathrm{ml} l\right)\end{array}$ \\
\hline $\begin{array}{l}1 / 1 \\
1 / 5 \\
1 / 25 \\
1 / 125\end{array}$ & $\begin{array}{l}3 \cdot 7 \\
3 \cdot 3 \\
3 \cdot 5 \\
1 \cdot 5\end{array}$ & $\begin{array}{l}3 \cdot 6 \\
3 \cdot 8 \\
3 \cdot 2 \\
2 \cdot 1\end{array}$ & $\begin{array}{l}1.7 \\
1.6 \\
0.9 \\
0.6\end{array}$ & $\begin{array}{l}3 \cdot \vdots \\
2 \cdot 3 \\
0 \cdot 3 \\
0 \cdot 3^{3}\end{array}$ \\
\hline
\end{tabular}

The figures in parentheses refer to the infectivity of the virus and fractions before inactivation with 0.05 per cent acetylethyleneimine. The neutralizing activity is the average of 4 sera in each group and is expressed as the activity in $0.015 \mathrm{ml}$. of $1 / 10$ serum.

Fractionation of virus suspensions by centrifugation in sucrose gradients provided evidence that material smaller than the complete virus particle protected mice against challenge. In addition, suspensions which had been treated with 'Tween'-ether and the residual infectivity inactivated with acetylethyleneimine produced neutralizing antibody levels in mice which were much higher than could be accounted for by the residual virus.

These experiments provide evidence that material smaller than the complete virus particle may be potentially useful in rabies vaccination.

We thank $\mathrm{Dr}$ A. C. Allison for virus seed and $\mathrm{Mr} \mathrm{H}$. H. Skinner for mice free from lymphocytic choriomeningitis virus and for showing that our rabies virus was also free from this agent.

\section{JOAN C'RICK}

F. BROW

Animal Virus Research Institute,

Pirbright, Surrey.

Received December 23, 1968; revised February 5, 1969.

${ }^{1}$ Wilcox, W. C., and Ginsberg, H. S., Proc. Soc. Exp. Biol. and Med.. 114, 37 (1963).

${ }^{2}$ Mussgay, M., and Rott, R., Virology, 23, 573 (1964).

3 Davenport, F. M., Hennessy, A. V., Brandon, F. M., Webster, R. $C_{\text {, }}$ Barrett, C. D., and Lease, G. O., .j. Lab. Clin. Yed., 63, 5 (1964).

- Norrby, E. C. T., Lagercrantz, R., and Gard, S., Proc. Soc. Gen. Mirrobiol., 37, iv (1964).

${ }^{5}$ Brown, F., Cartwright, B., and Almeida, J. D., J. Immunol., 96, 537 (1966). - Schmidt, N. J., Lennette, E. H., Gee, P. S., and Dennis, J., J. Immunol., 100, 851 (1968).

' Habel, K., Laboratory Techniques in Rabies, 140 (WHo, 1966).

${ }^{8}$ Van den Ende, M., Polson, A., and Turner, G. S., J. Hyg.. 55, 361 (195i).

\section{Spontaneous "Secondary" Disease in Germfree AKR Mice}

Diseases which develop in gnotobiotic (germfreo, mice reflect defects in the nutritional, genetic or microbial status of the host. Three viral agents have been detected so far in germfree mice, and these appear to bo passed to their progeny by congenital route(s). All mouse strains carry leukaemia virus ${ }^{1}$, some strains carry mammary tumour virus ${ }^{2}$ and one strain earries lymphocytic choriomeningitis (LCM) virus ${ }^{3}$. Except for these, germfree mice are free of bacteria, fungi and parasites. They are roferred to here as germfree, on the understanding that they are not free of virus. Spontaneous lymphatic leukaemia develops only in the AKR strain: in other strains (Balb/e, ICR, CFW, C3H, Swiss-Webster and ( $57 \mathrm{BL})$ lymphatic leukaemia must be elicited by whole body exposure to X-rays ${ }^{4,5}$. Germfreo mice of the AKR strain develop the same type and incidence of spontaneous lymphatic leukaemia as the conventional stock from which they were 